\title{
Introductory Experiments in Recombinant DNA
}

\author{
Robert C. Tait* \\ 2318 Cezanne Court, Davis, CA 95616, USA
}

\begin{abstract}
Nine practical exercises demonstrate the basic principles in recombinant DNA. The exercises explain the principles that DNA equals genes and that changes in DNA cause changes in genetic properties. The aim is to provide a teaching resource that can be used to illustrate the theory and applications of molecular biology to highschool students, undergraduate students, medics, dentists, doctors, nurses, life scientists, and anyone learning the basics of DNA technology.
\end{abstract}

\section{Introduction}

The exercises contained in this article have been chosen to demonstrate the basic principles in recombinant DNA: digestion of DNA with a restriction endonuclease, gel electrophoresis of DNA samples, insertion of DNA into cells can change their growth characteristics, and DNA can be rearranged to cause changes in genetic properties. The exercises are intended to be an example of the principles that DNA equals genes and that changes in DNA cause changes in genetic properties.

Each exercise is preceded by a short discussion of the principles involved and the specific goals of the procedure. Solutions that must be prepared for each exercise are detailed in a Materials section. While some of these "recipes" can be changed considerably without affecting the outcome of the exercise, many of the "minor" details are crucial to the success of the protocol. For example, a restriction digestion buffer may contain only 6 $\mathrm{mM} \mathrm{NaCl}$ relative to $50 \mathrm{mM}$ TRIS-Cl buffer, an apparently trivial amount of salt in the overall scheme of things. However, many enzymes are very specific about salt concentrations required for activity, and deleting the $\mathrm{NaCl}$ from the buffer may inactivate or actually change the recognition properties of the enzyme. Please do not arbitrarily change recipes and expect exercises to work properly.

The recipes assume a simple knowledge of chemistry and use standard abbreviations regarding concentrations:

$$
\begin{aligned}
& \mathrm{M}=\text { moles/liter }=\text { molar } \\
& \mathrm{mM}=\text { millimoles } / \text { iter }=10^{-3} \text { moles/liter = millimolar } \\
& \mathrm{I}=\text { liter } \\
& \mathrm{ml}=\text { milliliter }=10^{-3} \mathrm{liter} \\
& \mu \mathrm{l}=\text { microliter }=10^{-6} \text { liter }
\end{aligned}
$$

When $\mathrm{pH}$ of a solution is indicated, there is generally an allowance of about $0.5 \mathrm{pH}$ unit. If a pH of 7.5 is indicated, a pH of 7.0 to 8.0 will generally suffice. If possible, use a $\mathrm{pH}$ meter in the preparation of solutions, otherwise, use $\mathrm{pH}$ paper and be as accurate as reasonable.
The instructions often require the addition of water, sometimes indicated specifically as distilled water $\left(\mathrm{dH}_{2} \mathrm{O}\right)$. For electrophoresis, media, and general solutions, tap water will often suffice. For reactions involving enzymes, distilled water should always be used rather than tap water. Many enzymes can be inhibited by heavy metal salts present at low levels in tap water. Distilled water purchased for use in a steam iron can be used in the event that there is no access to a water still or deionizer.

Certain solutions must be sterilized (media for culture of bacteria, for example). An electric hot plate and a standard pressure cooker can be used as a substitute for an autoclave. Heat media at $16 \mathrm{lb}$ pressure for 20-30 minutes to sterilize small volumes of liquids (less than 500 $\mathrm{ml}$ solution per container). While a microwave oven is used for melting agarose in nearly every molecular biology research lab, a hot plate with a boiling water bath or a gas burner will accomplish the same thing. Agarose solutions have a tendency to superheat and boil violently when the agarose granules are first melting. A solution of agarose that has been previously melted, then allowed to cool and solidify is less likely to boil violently when melted the second time.

As a note of caution, realize that molecular biology uses a number of noxious chemicals: organic solvents (phenol, chloroform, ether) are quite toxic and certain compounds (ethidium bromide and UV light, for example) are known mutagens capable of causing genetic changes. The use of such compounds has been kept to a minimum in these exercises and where such compounds are used, precautions are noted in directions for the exercises. During electrophoresis, although low voltages are used, severe injury is possible. Electrophoresis boxes should have an interlock mechanism - a device that prevents the current from being applied to the buffer when the buffer is exposed. Most commercial gel boxes include this safety design feature, as do the plans that accompany these exercises. COMMON SENSE IS REQUIRED IN ALL LAB EXERCISES. Food and drinks should be prohibited from the work area and lab coats should be worn. Power units should be turned off while loading gels or handling gel boxes. All spills should be cleaned up when they occur.

Having previously indicated that these exercises should not be arbitrarily altered, I now emphasize that these protocols should not be considered inviolate. There are about 113 ways to accomplish the same thing in any molecular biology exercise. As your understanding of these methods increases, you will recognize how protocols can be altered to suit a particular circumstance. Other protocols will appear that seem easier or more reproducible in your own situation. While this is one of the aspects of molecular biology that makes the methods so powerful, this variability also tends to unnecessarily confuse novices in the field. Before modifying a protocol, be certain that you understand the changes and that these alterations will not adversely affect the outcome of an exercise.

The bacteriophage lambda, pBR322, and pUC19 plasmid DNA samples used in these exercises are available from a number of commercial suppliers. The bacterial DNA 
can be prepared by a simple procedure (see Appendix) that uses detergent lysis and phenol/chloroform extraction to prepare high quality DNA. Commercially available calf thymus DNA can be substituted. Plasmid recombinants containing $E$. coli DNA in pUC19 were chosen specifically to work entirely with bacterial DNA and minimize any misperception of biohazard potential. Competent cells are commercially available from several sources, but acceptable competent cells can also be prepared with a minimum of expertise.

\section{Exercise 1. Gel electrophoresis of nucleic acids}

Nucleic acid samples are often subjected to gel electrophoresis to characterize the size and number of different fragments in the sample. In this exercise, DNA samples that have been digested with restriction enzymes and mixed with a tracking dye will be subjected to agarose gel electrophoresis. The electrophoresis buffer, the salt solution that both conducts electric current and controls the $\mathrm{pH}$ of the solution during the separation of the DNA fragments, is TRIS/borate/EDTA or TBE, a commonly used buffer system.

When charged molecules are placed in an electric field, the molecules will migrate towards one of the electrodes, depending on the net charge of the molecule. Nucleic acids have an overall negative charge due to the negative charges associated with the phosphate backbone of the molecules, so they will migrate towards the positive electrode. Since the distribution of phosphate is very regular across the length of the nucleic acid molecule, nucleic acids have a constant charge/mass ratio and will therefore migrate at the same rate in an electric field.

Separation of nucleic acid molecules of different size or conformation is achieved by adding a support matrix to the electric field and forcing the molecules to migrate through this matrix, typically agarose or polyacrylamide gel. This matrix acts like a sieve that allows small molecules to go faster than large molecules. The result is that molecules separate in the matrix according to their relative size and shape.

This exercise will use gel electrophoresis to examine the fragments present in several DNA samples. The principle goal is to obtain experience in pouring gels, loading DNA samples, and visualizing the DNA bands.

Due to the small volumes of sample to be applied to the gel, samples are routinely handled with a manual micropipet device that uses a disposable plastic tip to handle a 10 to $20 \mu \mathrm{l}$ sample. Several commercial devices are available. A substitute sample loader can be assembled from a disposable 0.5 or $1 \mathrm{ml}$ syringe fitted with a disposable plastic tip (see Appendix)

\section{Materials}

- EcoRl- and Hindlll-digested bacteriophage lambda DNA samples containing SM Dye (other DNA samples can be added or substituted).

- Reaction Stop Mix Dye (SM Dye): $10 \%$ glycerol, 0.5\% SDS (sodium dodecyl sulphate), $0.025 \%$ xylene cyanol FF dye (XC), $0.025 \%$ bromphenol-blue WS dye (BPB). This mix is added to a DNA sample after digestion to prepare the sample for electrophoresis. The SDS helps inactivate DNA binding proteins and releases them from the DNA fragments and the glycerol weights the sample so that it will layer uniformly into the slots in the gel. The two dyes serve as visual markers of the progress of the electrophoresis only and do not stain DNA or proteins. The purple BPB dye will migrate with about twice the relative mobility of the turquoise $\mathrm{XC}$ dye.

- TBE electrophoresis buffer: $90 \mathrm{mM}$ TRIS, $2.5 \mathrm{mM}$ $\mathrm{Na}_{2}$ EDTA, 89 mM boric acid, final pH 8.2 (can be stored as a $10 \mathrm{x}$ stock).

- $1 \%$ Agarose: Molten $1 \%$ agarose in TBE buffer, heated to $100^{\circ} \mathrm{C}$ to melt the agarose and stored in $55^{\circ} \mathrm{C}$ water bath until needed. Melt the agarose very carefully to minimize superheating and violoent boiling.

- Ethidium bromide (EtBr): For staining gels to visualize DNA, approximately $200 \mathrm{ml}$ of $4 \mu \mathrm{g} / \mathrm{ml}$ ethidium bromide in water in a shallow tray, stored covered and protected from excessive light exposure. EtBr should be treated as a mutagen - a compound capable of causing genetic mutations - and bare skin should not come in contact with the solution. It is both photosensitive and biodegradable and dilute solutions are often disposed of via the sink. Concentrated solutions must be saved and disposed of as biohazardous chemical waste.

\section{Protocol}

1. Use the molten agarose to pour a minigel as demonstrated or according to instructions for the gel unit in use. Illustrations for assembling a generic gel unit are included in the Appendix. It is important to be certain that all small agarose particles are completely melted before use. Allow the gel to completely harden before removing the well-forming comb. This should take about 15 minutes.

2. Remove the comb from the solidified gel and transfer the gel to a running unit. Submerge the gel in TBE buffer.

3. Use a manual pipettor with a disposable plastic tip to load $10 \mu \mathrm{l}$ of each sample into one of the wells in the gel. Plasmid and bacteriophage DNA samples should be easy to load, but chromosomal DNA samples may be quite viscous and difficult to load.

4. Once the samples have been loaded, close the unit and apply power to the electrophoresis chamber. Typical minigels run at $100-130$ volts $(60-160$ milliamps), depending on the unit used. During the run, the $\mathrm{XC}$ and $\mathrm{BPB}$ dyes will resolve into two bands, with the BPB the faster band. Run the gel until this band is near the end of the gel, then turn the current off and remove the gel.

5. Transfer the gel to the staining tray containing the ethidium bromide solution, and stain the gel for 5 minutes. Ethidium bromide is a mutagen, and gloves should be worn or a spatula used to transfer the gel in and out of the ethidium solution.

6. Transfer the stained gel to a destaining tray containing water. Destain the gel for 5 minutes to remove excess ethidium bromide.

7. The stained gel can be visualized with a UV transilluminator or a UV mineral lamp. DO NOT LOOK DIRECTLY AT THE UV LIGHT!! UV light causes skin burns, is a mutagen, and will cause severe headaches from eye damage with direct exposure. Always use a face mask or shield. 
Analysis and significance of results

The results of a typical gel are shown illustrated below:

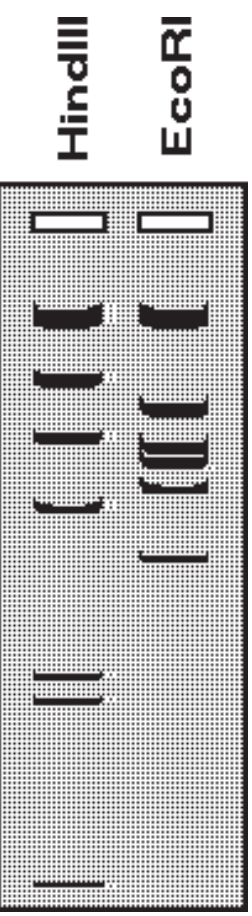

If lambda DNA samples digested with different restriction endonucleases are present on the same gel, note that each different restriction enzyme produces a distinct, completely reproducible pattern of DNA fragments. Relative separation of individual fragments is dependent on agarose concentration, electrophoresis conditions, and the quality of the gel preparation.

Many different types of artefact can distort the bands in a gel. Some of the more common gel artefacts are illustrated below.

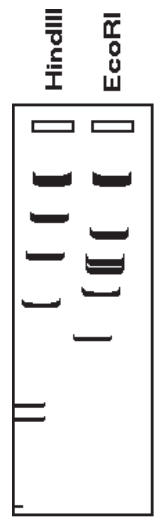

a b

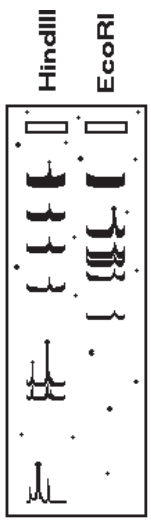

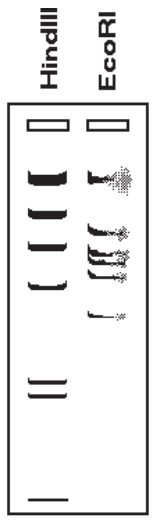

C

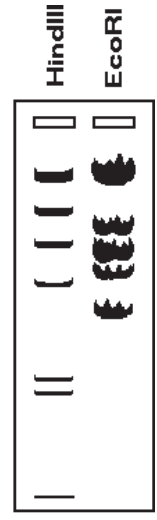

d a. Gel was crooked in gel box and samples migrated off of the gel.

b. Agarose was not completely melted before gel was poured. The small specks of high concentration agarose in the gel cause distortion in DNA bands and bright spots in the gel.

c. The sample well containing the EcoRI-digested lambda DNA leaked at the right side, causing loss of sample intensity and blurring of bands.

d. The smearing of the EcoRI-digested lambda DNA is caused by loading too much DNA.

During electrophoresis of DNA fragments through an agarose gel, the fragments separate by size with smaller fragments moving faster than larger fragments. The relationship between size and mobility is not linear, but can be approximated by plotting the distance migrated versus the log(Molecular Weight).

1\% Agarose gel
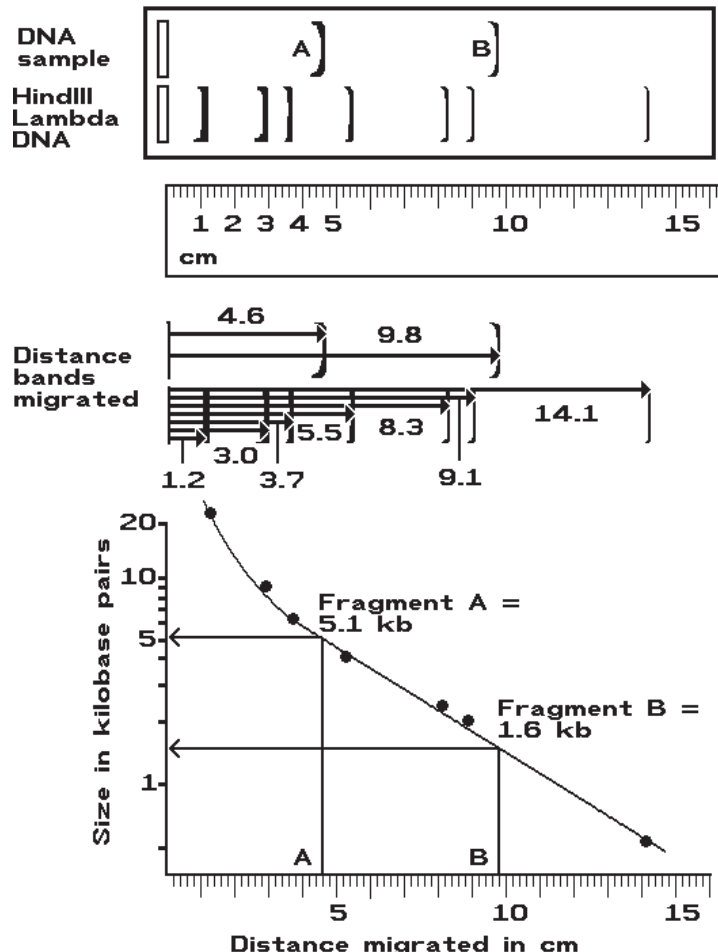

Using the Hindlll fragments as molecular weights standards to estimate the size of other DNA fragments. Mobility of fragments is determined and plotted as log(Size) versus mobility. The line drawn through the lambda DNA fragments can be used as a standard curve for determination of sizes of other DNA fragments present on the same gel.

\section{Exercise 2. Restriction endonuclease digestion of chromosomal and plasmid DNA}

Digestion of DNA with a site-specific restriction endonuclease will generate a set of specific DNA fragments. In this exercise, a variety of DNA samples will be digested with the restriction enzyme EcoRI. This enzyme recognizes and cleaves the sequence 5'-GAATTC-3' between the $G$ and $A$ residues to generate the four-base cohesive terminus AATT:

$\begin{array}{lll}5^{\prime} \text {-NNNNGAATTCNNNN-3' } & \text { ECORI } & 5^{\prime} \text {-NNNNG AATTCNNNN-3' } \\ 3^{\prime} \text {-NNNNCTTAAGNNNN-5' } & ------> & 3^{\prime} \text {-NNNNCTTAA GNNNN-5' }\end{array}$

Because EcoRI recognizes and cleaves at a six-base sequence (5'-GAATTC-3'), the number of fragments generated by digestion of a DNA molecule with this enzyme 
is determined approximately by the frequency of occurence of the recognition site. Since there are four possible bases that can occur at any position in DNA $(A, C, G, T)$ the probability of occurence of a specific base is (1/4), while that of a specific two-base sequence is $(1 / 4)^{2}$, a four-base sequence $(1 / 4)^{4}$, and a six-base sequence is $(1 / 4)^{6}$. The six-base EcoRI site, therefore, should occur about once every $4^{6}$ bases, or once every 4096 base pairs. EcoRI cleaves the 2,800 base pair plasmid pUC19 only once and will convert the circular molecule to a linear form, cleaves the linear 50,000 base pair bacteriophage lambda DNA five times to generate six fragments, cleaves hundreds of times in the E. coli DNA genome, and thousands of times in eukaryotic DNA. The larger the genome of an organism is, the greater the number of fragments generated during digestion with a restriction enzyme.

Several DNA samples from genomes of increasing size will be digested with EcoRI in this exercise. If both the enzyme digestion and the gel analysis are to be performed in the same day, as soon as the digestion reactions have been set up and are incubating, prepare agarose minigels for analysis of the digested DNA samples.

\section{Materials}

- $\quad$ Plasmid pUC19 vector DNA: $100 \mu \mathrm{g} / \mathrm{ml}$.

- Bacteriophage lambda DNA: $100 \mu \mathrm{g} / \mathrm{ml}$.

- Bacterial chromosomal DNA: $100 \mu \mathrm{g} / \mathrm{ml}$.

- $\quad$ EcoRI endonuclease: 3-5 units/ $\mu$ l. Keep this in ice at all times!!

- 10x EcoRI Reaction buffer: 500 mM TRIS-HCI pH 7.0, $750 \mathrm{mM} \mathrm{NaCl}, 60 \mathrm{mM} \mathrm{MgCl}_{2}, 60 \mathrm{mM}$ 2mercaptoethanol. Most enzyme companies supply the correct buffer with each enzyme purchased.

- Water $\left(\mathrm{dH}_{2} \mathrm{O}\right)$ : Sterile, deionized or distilled.

- Manual pipet devices, 1-20 $\mu$ land 20-200 $\mu$ l capability.

- Disposable conical $1.5 \mathrm{ml}$ microfuge tubes and pipet tips.

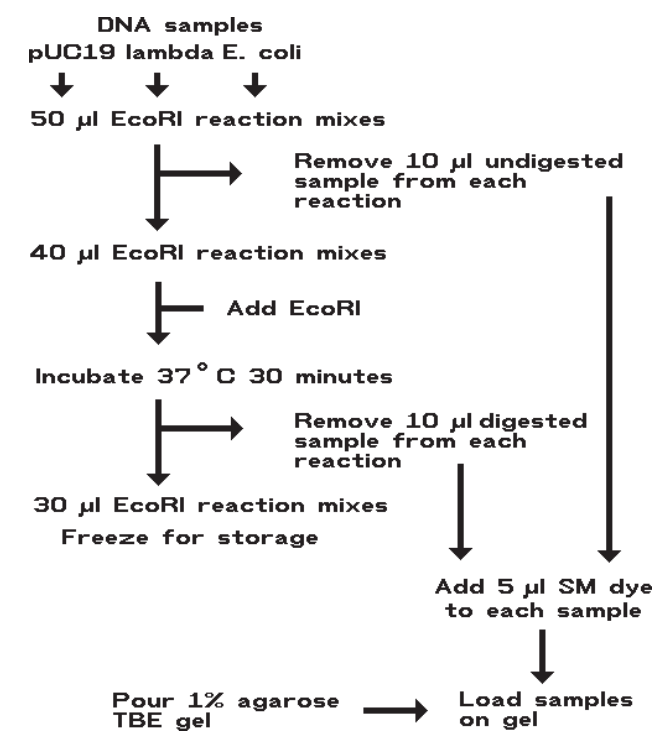

\section{Protocol}

1. For each different chromosomal DNA sample, set up a digestion reaction in a labeled $1.5 \mathrm{ml}$ conical tube by making the following additions:

$\begin{array}{ll}\text { 10x EcoRI buffer } & 5 \mu \mathrm{l} \\ \mathrm{dH}_{2} \mathrm{O} & 35 \mu \mathrm{l} \\ 1 \text { ug DNA } & 10 \mu \mathrm{l} \\ \text { Total volume } & 50 \mu \mathrm{l}\end{array}$

2. Mix the contents of the tubes gently but thoroughly, then from each tube remove $10 \mu \mathrm{l}$ and place in a tube labeled with the sample number and the term "-EcoRl". Place these $10 \mu \mathrm{l}$ samples on ice. They are the undigested controls and will be used to compare to samples following digestion.

3. To the remaining $40 \mu \mathrm{l}$ of each sample add:

EcoRI, 5-10 units $\quad 2 \mu \mathrm{l}$

Mix, then incubate at $37^{\circ} \mathrm{C}$ for 30 minutes.

4. From each digestion tube, remove $10 \mu \mathrm{l}$ of each sample and add to a tube labeled with the sample name and "+EcoRl". The remainder of each digestion reaction should be frozen for further use.

5. You should now have two tubes containing $10 \mu \mathrm{l}$ of each DNA sample, one "-EcoRl" and one "+EcoRl", for a total of six tubes. To each of these tubes add:

$$
\text { SM dye } \quad 5 \mu \mathrm{l}
$$

Mix the contents of each tube, and the samples are ready for electrophoresis. Samples can be stored on ice or frozen for future gel electrophoresis.

\section{Significance of procedure}

This exercise has prepared reaction mixes that contain several DNA samples of different sizes and conformations, then digested portions of each reaction mix with the restriction enzyme EcoRI. The samples are now ready for analysis by agarose gel electrophoresis to determine the effects of the restriction enzyme digestion. The same gel electrophoresis described in Exercise 1 will be utilized.

\section{Materials}

- DNA samples prepared in Exercise 2.

- Electrophoresis materials, see Exercise 1.

\section{Protocol}

1. Prepare a $1 \%$ agarose gel in TBE buffer as in Exercise 1.

2. When the gel has solidified, assemble the gel unit. Load $15 \mu \mathrm{l}$ of each of the six samples. You may also want to include one lane of the digested lambda DNA used in the first exercise as a DNA standard. Electrophorese as in Exercise 1.

3. Stain the gel with ethidium bromide and visualize the DNA bands with a UV light box. A photograph of the gel is useful, but a sketch of the gel is sufficient for recording information. 
Analysis and significance of results

A typical gel is illustrated below:

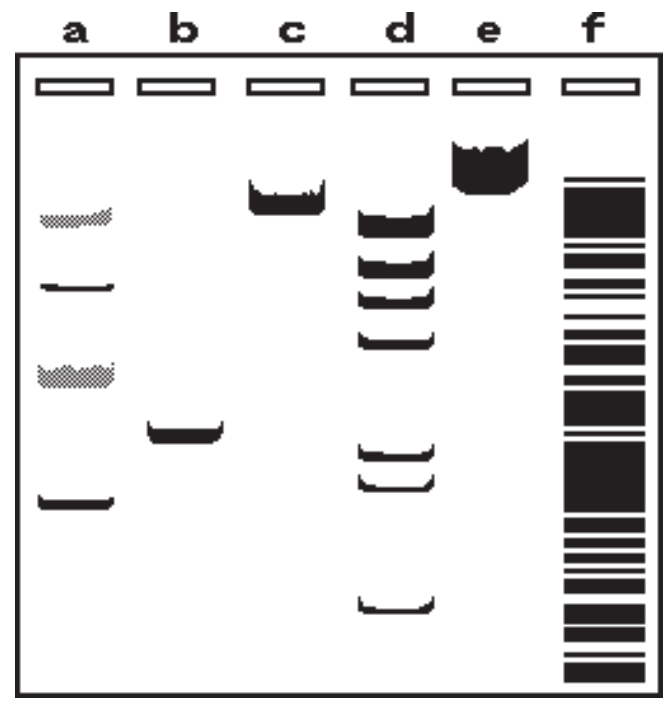

Compare each undigested (-EcoRI) with the corresponding digested $(+E c o R I)$ sample. Note that the migration position of the undigested circular plasmid pUC19 DNA (a) changes when cleaved at the unique EcoRI site to generate a linear molecule (b). The linear undigested lambda DNA (c) contains five EcoRI cleavage sites, and migrates as six bands after digestion (two of the bands are of similar size and can be difficult to resolve, but this double band will be twice as intense as the other bands) (d). The slowly migrating, broad, undigested bacterial chromosomal DNA sample (e) is converted upon digestion to hundreds of smaller, yet distinct bands (f). Note that as the size of the genome (pUC19<lambda<E. coli) increases, the number of cleavage sites also increases, demonstrating that larger genomes are actually composed of larger amounts of DNA.

\section{Exercise 3. Competent cell production}

Although some bacteria naturally undergo a growth phase when they are capable of taking up DNA, strains of E. coli, the bacteria most commonly used in a molecular biology lab, cannot normally take up DNA. These bacteria must be chemically treated to be made competent for transformation. Competent cells can be purchased from a variety of commercial sources but can be relatively expensive for routine classroom demonstrations and laboratories. Cells can be made by harvesting rapidly growing bacteria and exposing them to calcium chloride on ice. The following protocol can be used to make competent $E$. coli that are of sufficient quality for routine use.

\section{Materials}

- $\quad 35 \mathrm{ml}$ LB medium (1\% Bacto Tryptone, 0.5\% Bacto Yeast Extract, $0.5 \% \mathrm{NaCl}, \mathrm{pH} 7.0-7.2)$ in sterile 100 $250 \mathrm{ml}$ flask.

- $\quad$ Fresh $2 \mathrm{ml}$ overnight LB culture of JM83.

- Sterile 50 or $35 \mathrm{ml}$ centrifuge tube.

- Sterile $30 \mathrm{mM} \mathrm{CaCl}_{2}$.
- Sterile $30 \mathrm{mM} \mathrm{CaCl}_{2}, 15 \%$ glycerol.

- $\quad$ Sterile microfuge tubes.

- Ice.

- Refrigerated centrifuge. If a refrigerated centrifuge is not available, place a clinical or counter-top centrifuge in a refrigerator. Allowing the cells to warm up during the centrifugation may affect the competency of the cells.

\section{Protocol}

1. Competent cells must be made from a rapidly growing culture of bacteria to obtain good efficiencies of transformation. Mid-logarithmic phase of growth (3-5 $\times 10^{8}$ cells $/ \mathrm{ml}$ ) is good for preparation of general-use competent cells. With a fresh overnight innoculation culture, a 1:50 dilution into a fresh culture will generally give mid-log cells in $60-90$ minutes of growth at $37^{\circ} \mathrm{C}$. If an old overnight culture is used or if insufficient dilution is made, the bacteria will undergo a significant lag phase before growth begins.

2. Use sterile techniques to transfer $0.7 \mathrm{ml}$ of the overnight culture of JM83 to the flask containing $35 \mathrm{ml}$ of LB. Incubate in a $37^{\circ} \mathrm{C}$ shaker with vigorous shaking to allow growth. Monitor the growth of the culture every 20 minutes $\left(A_{550}\right)$. When absorbance is approximately 0.5 , the culture is ready to harvest. This should correspond to a mid-logarithmic phase of growth. If a semi-log plot of $A_{550}$ versus time is prepared, harvest of cells should occur in the linear portion of the graph.

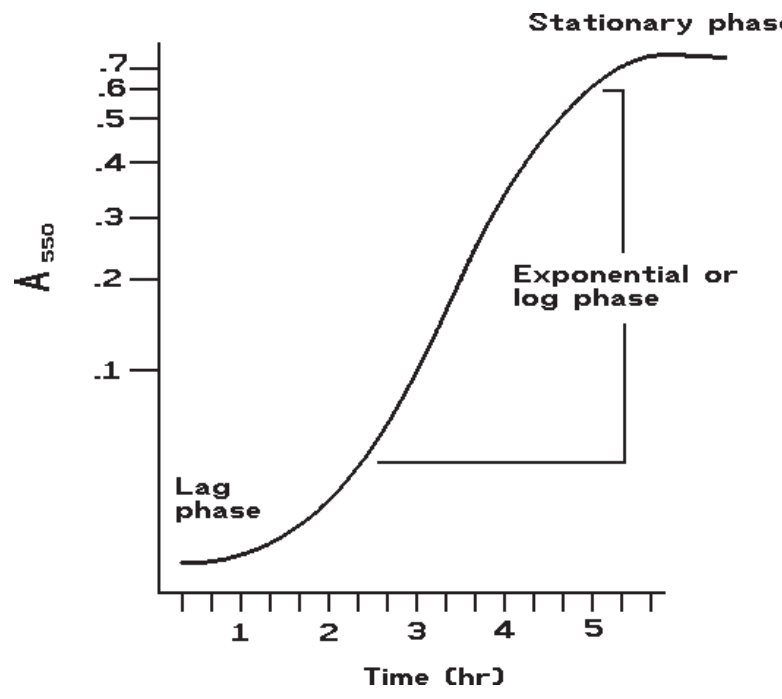

3. Although strict sterile technique is not necessary, try to minimize contamination of the cells throughout the following procedures. Pour the culture into a sterile centrifuge tube. Spin $7000 \mathrm{rpm}, 5$ minutes to pellet the cells.

4. Pour off the supernatant. Add $17.5 \mathrm{ml}$ of cold $30 \mathrm{mM}$ $\mathrm{CaCl}_{2}$ (1/2 of the original culture volume). Gently resuspend the cells.

5. Place cells on ice for 20 minutes. Cells will swell to form spheroplasts. Cells can incubate on ice as long as 90 minutes.

6. Centrifuge $7000 \mathrm{rpm}, 5$ minutes, at $4^{\circ} \mathrm{C}$.

7. Pour off supernatant. Many strains of $E$. coli often form a halo instead of a normal pellet. 
8. Add $3.5 \mathrm{ml}$ of cold $30 \mathrm{mM} \mathrm{CaCl}, 15 \%$ glycerol. GENTLY RESUSPEND THE CELLS. If resuspension is too harsh, competency may decrease. Return cell suspension to ice.

9. Label 17 sterile microcentrifuge tubes "cJM83". Aliquot $200 \mu \mathrm{l}$ of competent cells into each tube. Cap tubes. Cells can be used immediately or stored in a freezer for future use. To freeze, move the tubes to a prechilled rack in the freezer for storage. Cells can be stored at $-20^{\circ} \mathrm{C}$ (normal lab freezer) for several weeks or at $-70^{\circ} \mathrm{C}$ for months without significant loss of competency. Recombination deficient strains (recAstrains, in particular) rapidly lose viability/competency when stored in a freezer.

10. If competent cells are made and stored for use in a lab exercise, it is wise to transform one tube with a pure plasmid DNA sample prior to use to verify that the cells have not lost competency during storage. Larger numbers of competent cells can be prepared by scaling all procedures up as needed. When culture volumes are increased, be certain that the culture has a large surface area to maintain adequate aeration in the growing culture.

\section{Exercise 4. Transformation of competent cells with pUC19 and pUC19 recombinants}

DNA molecules can be inserted into bacteria by first chemically treating the bacteria to make them competent, or able to take up DNA. This chemical treatment is often accomplished by exposing the bacteria to specific salts that cause the bacteria to swell and become capable of binding DNA. Treatment of $E$. coli with $\mathrm{CaCl}_{2}$ gives reproducible transformation results, although higher levels of competency can be attained with other procedures. After exposing the competent cells to DNA on ice, a $43^{\circ} \mathrm{C}$ heat shock is required to make the competent cells take up the bound DNA.

In this exercise, E. colistrain JM83 will be transformed with the plasmid pUC19. This plasmid contains genes that allow its own replication in the bacterium and contains a gene (bla) that encodes B-lactamase, an enzyme that confers resistance to ampicillin. The host strain JM83 is sensitive to and will not grow in the presence of ampicillin, while JM83 containing pUC19, indicated by JM83(pUC19), will grow and form colonies in the presence of the antibiotic.

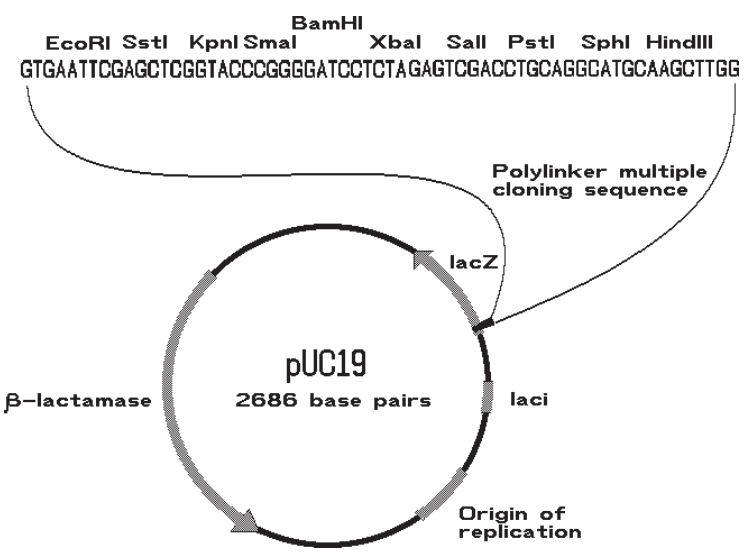

This plasmid also contains a genetically engineered portion of the lac operon of E. coli. When exposed to the inducing compound IPTG, cells containing pUC19 synthesize the enzyme $B$-galactosidase. This activity can convert the colorless compound X-gal to a blue compound during the growth of the cells. When the strain JM83(pUC19) is plated on medium containing ampicillin, IPTG and X-gal, the resulting colonies will be dark blue in color.

The plasmid pUC19 was designed with a series of unique restriction cleavage sites within the coding region of the $B$-galactosidase gene. This region, designated the multiple cloning site or MCS, is used for the specific insertion or cloning of extra DNA fragments. When a fragment is inserted, the $\beta$-galactosidase gene is interrupted and the enzyme can no longer be synthesized. Thus, a strain containing pUC19 with an extra DNA insert, designated JM83(pUC19:insert), will still form colonies in the presence of ampicillin, but in the presence of IPTG and X-gal the colonies will remain white rather than blue. Thus, bacteria containing the wild-type pUC19 vector can be distinguished from cells containing a recombinant pUC19 plasmid with an extra DNA insert.

To transform cells with pUC19, the competent cells will be placed at $43^{\circ} \mathrm{C}$, then directly plated on nutrient plates containing $100 \mathrm{ug}$ ampicillin $/ \mathrm{ml}$ as a selective antibiotic. Incubation of the plates at $37^{\circ} \mathrm{C}$ will allow colonies to form. The presence of the compounds IPTG and X-gal will be used to distinguish the original vector from recombinant derivatives containing DNA inserts. The wild-type vector will cause the formation of blue colonies and recombinant derivatives present in the pUC19:E. coli DNA library will cause the formation of white colonies.

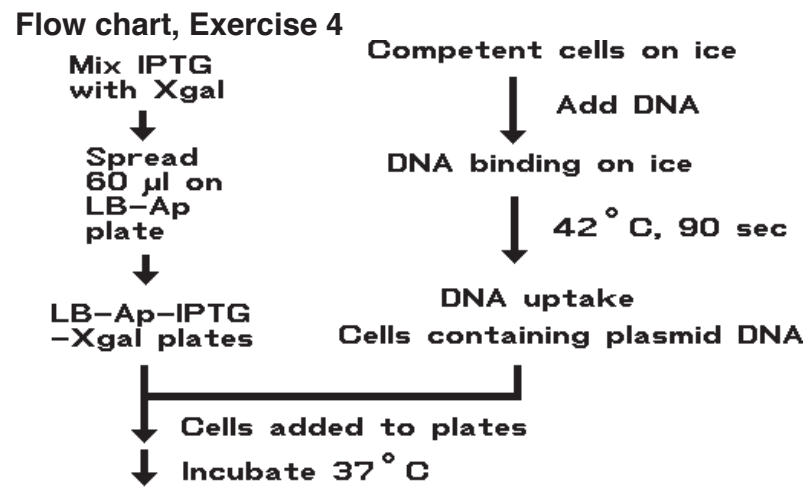

Transformed colonies

\section{Materials}

- $\quad$ Plasmid pUC19 vector DNA: $100 \mu \mathrm{g} / \mathrm{ml}$.

- pUC19:E. coli library DNA: $100 \mu \mathrm{g} / \mathrm{ml}$.

- Competent E. coli cells: $\mathrm{CaCl}_{2}$ treated competent JM83 cells, $100 \mu$ l aliquots, stored $-20^{\circ} \mathrm{C}$.

- Sterile $\mathrm{dH}_{2} \mathrm{O}$.

- LB agar plates containing ampicillin for selection of pUC19 transformants: 1\% Bacto Tryptone, 0.5\% Bacto Yeast Extract, $0.5 \% \mathrm{NaCl}, 1.5 \%$ Bacto agar, $\mathrm{pH} 7.0-$ 7.2. Autoclave to sterilize, cool to $50^{\circ} \mathrm{C}$, add ampicillin to $100 \mu \mathrm{g} / \mathrm{ml}$, pour petri plates, and cool. Other complete E. coli nutrient media can be substituted, as long as ampicillin is present. Do not use minimal media, as most laboratory strains of bacteria have several nutritional deficiencies that require specific supplements that are generally present in rich media. 
- 10 mM IPTG: 23.8 mg IPTG (isopropyl- $\beta-D-$ thiogalactopyranoside) $/ \mathrm{ml} \mathrm{dH}_{2} \mathrm{O}$.

- $\quad 5 \%$ X-gal: $50 \mathrm{mg} \mathrm{X-Gal} \mathrm{(5-bromo-4-chloro-3-indolyl-}$ $\beta$-D- galactopyranoside)/ml dimethylformamide.

- $43^{\circ} \mathrm{C}$ temperature block or water bath.

- $37^{\circ} \mathrm{C}$ incubator.

\section{Protocol}

1. Prepare six LB-Ap plates for transformation by adding IPTG and X-gal to each plate. To a sterile tube add 60 $\mu 110 \mathrm{mM}$ IPTG and $300 \mu \mathrm{l} 5 \% \mathrm{X}$-gal. Mix solution. Place $60 \mu$ of this IPTG/X-gal mix on the surface of an LB-Ap plate. Dip a glass spreader in $95 \%$ ethanol and flame to sterilize. Use the spreader to distribute the IPTG/X-gal mix evenly over the surface of the plate. Replace the lid on the plate and invert the plate. Repeat this process for each of the remaining 5 plates. If you attempt do do all of the plates at the same time, the solution may soak into the center of the plates and will not be uniformly distributed over the surface. Allow the solution to soak into the surface of the plates for $15-30$ minutes (if possible, place the plates in a $37^{\circ} \mathrm{C}$ incubator during this time period).

2. Thaw three tubes of competent cells at room temperature. As soon as cells are thawed, label one tube "-DNA", one tube "+pUC19", and one tube "+library" and place all tubes on ice.

3. To the "-DNA" tube add $10 \mu \mathrm{l}$ sterile $\mathrm{ddH}_{2} \mathrm{O}$, to the "+pUC19" tube add $10 \mu \mathrm{l}(1 \mu \mathrm{g})$ of pUC19 DNA, and to the "+library" tube add $10 \mu$ of pUC19:EC library DNA. Place tubes on ice for at least 15 minutes (length of time is not crucial here). This allows DNA to bind to the competent cells. While tubes are on ice, adjust a water bath to $42-43^{\circ} \mathrm{C}$.

4. Heat pulse the cells to cause DNA uptake. Transfer all three of the tubes of competent cells containing DNA to the $42^{\circ} \mathrm{C}$ bath for 90 seconds, then transfer to a room temperature rack.

5. Add $10 \mu \mathrm{l}$ of one of the transformed cell samples to an LB-Ap-IPTG-Xgal plate and the rest $(100 \mu \mathrm{l})$ to another plate. Dip the glass spreader in ethanol, flame, and use to distribute the cells evenly over the surface of each plate. Invert the plates and label with amount of cells and type of DNA (such as $10 \mu \mathrm{l}$, pUC19). Repeat for each of the tubes of transformed cells (you should end up with no tubes of transformed cells left over and have six labeled plates with cells spread on them). Place plates in a $37^{\circ} \mathrm{C}$ incubator for $12-18$ hours to allow colonies to form and color to develop. Plates can be stored in a refrigerator and color will continue to develop.

\section{Analysis and significance of results}

After the plates have been allowed to incubate and colonies have formed and colored, compare all the plates. The following results are typical:

- JM83 transformed with no DNA should give no distinct colonies but may have some smearing or poor growth in areas of dense numbers of cells.

- JM83 transformed with pUC19 DNA should give many distinct colonies, nearly all of which (>99\%) should be blue. The occasional white colony will be a contaminant or a mutant derivative of pUC19 in which the Bgalactosidase gene is no longer active. By counting the number of colonies on a plate and dividing by the amount of transforming DNA represented on the plate, it possible to calculate the efficiency of transformation in terms of transformants $/ \mu \mathrm{g}$ DNA. Example: $1 \mu \mathrm{g}$ of pUC19 DNA was added to $100 \mu \mathrm{l}$ of competent cells, and $1 \mu \mathrm{l}$ of this mix was plated on an LB-Ap plate, resulting in 227 colonies. The amount of DNA represented on the plate is $10 \mu \mathrm{l} / 110 \mu \mathrm{l} \times 1 \mu \mathrm{g}=0.1$ $\mu \mathrm{g}$. Transformation efficiency is 227 colonies $/ 0.1 \mu \mathrm{g}$, or $2.27 \times 10^{3}$ transformants/ $\mu$ g DNA.

- JM83 transformed with pUC19:E. coli library should give similar numbers of colonies when compared with the pUC19 transformation, but only a percentage of the colonies will be blue. The blue colonies are the result of transformation with pUC19 containing no additional DNA insert, and the white colonies are caused by transformation with recombinant pUC19 plasmids. The transformation efficiency can be calculated for the DNA as described above and the percentage of recombinant molecules can be determined by the calculation:

\section{0 x \# white colonies/\# total colonies.}

This exercise demonstrates two fundamental principles of recombinant DNA methods:

1. DNA can be inserted into bacteria to change the properties of the cells (ampicillin-sensitive cells converted to ampicillin-resistant colonies).

2. DNA fragments can be re-arranged to change the genetic properties of the DNA molecules (blue colonies caused by pUC19 are converted to white colonies when DNA fragments are inserted into pUC19 DNA).

These principles can be further examined by isolation and examination of plasmid DNA present in the transformant colonies.

\section{Exercise 5. Transformation of competent cells with pUC19 and pBR322 plasmid DNA}

One of the most important concepts of DNA biology is that genes are composed of DNA and that the introduction of DNA into a cell can change the physical properties of the cell. This can be illustrated with petri plates containing a simple nutrient medium (Luria broth, Tryptone, Nutrient agar, essentially any medium that will allow the growth of E. coli), a small amount of plasmid DNA, and competent E. coli bacterial cells.

This exercise uses E. coli JM83 cells that have been made competent, or able to take up DNA. The cells were grown to mid-logarithmic phase, then harvested and resuspended in $30 \mathrm{mM} \mathrm{CaCl}_{2}$. After incubation on ice for 30 minutes, the cells were again harvested and resuspended in $30 \mathrm{mM} \mathrm{CaCl}_{2}$ with $15 \%$ glycerol. Cells were dispensed into $0.2 \mathrm{ml}$ volumes in sterile $0.5 \mathrm{ml}$ tubes. Each of these tubes contains sufficient cells for at least 4 different transformation reactions. Competent cells may slowly lose their ability to take up DNA if not stored at $-70^{\circ} \mathrm{C}$. For this reason, the competent cells are shipped in dry ice to arrive the week before the exercise and are stored in a freezer at about $-5^{\circ} \mathrm{C}$ until used.

A DNA sample containing two types of pure plasmid DNA, pUC19 and pBR322, at a concentration of $100 \mu \mathrm{g} /$ $\mathrm{ml}$ will be used to demonstrate that DNA can change cellular 
properties. The plasmid pUC19, a common plasmid cloning vector used to carry and propagate other DNA fragments in bacteria, has two genes of interest: one confers resistance to the antibiotic ampicillin, and the other encodes a $B$-galactosidase gene derivative that produces a protein that can help the bacteria metabolize derivatives of the sugar galactose. When the colorless compound $\mathrm{X}$-gal is added to the growth medium, the $B$-galactosidase protein can metabolize the $\mathrm{X}$-gal into a colored derivative that turns the bacterial colonies blue.

The second plasmid DNA provided is pBR322, one of the older plasmid cloning vectors. Like pUC19, this plasmid confers resistance to ampicillin, but it also confers resistance to the protein synthesis inhibitor tetracycline. Just like bacteria containing pUC19, bacteria containing pBR322 will be able to grow in medium containing ampicillin. Since pBR322 does not contain the Bgalactosidase gene derivative, cells containing this plasmid will be unable to metabolize X-gal to a colored compound and will remain white when exposed to X-gal. Bacteria containing pBR322 will, however, be able to grow in the presence of a concentration of tetracycline that kills cells containing pUC19.

The bacterial strain JM83 is sensitive to ampicillin and will not grow on nutrient plates in the presence of the antibiotic at a concentration of $100 \mu \mathrm{g} / \mathrm{ml}$. When either pUC19 or pBR322 is inserted into the competent JM83 cells, the cells become transformed and are able to grow in the presence of the antibiotic. These two plasmids can thus cause the same change in bacterial phenotype - ability to grow in the presence of ampicillin - and this property cannot be used to distinguish between cells containing one of these two plasmids.

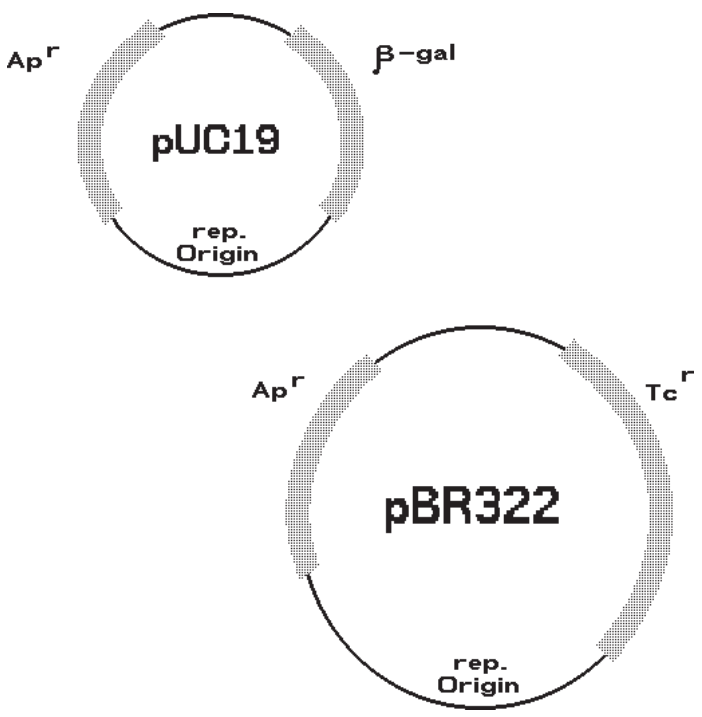

Genetic maps of the plasmids pUC19 and pBR322

However, if the compounds X-gal and IPTG are also added to the ampicillin plate, the B-galactosidase gene present on pUC19 will cause bacteria containing this plasmid to form blue colonies, while bacteria containing pBR322 will form white colonies. The difference in phenotype associated with these plasmids - ability of cells containing pUC19 to form a blue colony - allows rapid sorting of colonies formed by cells containing each of the two types of plasmid. This demonstrates that two plasmids that confer the same phenotypic property (such as ability to grow in the presence of ampicillin) can be readily distiguished if the plasmids differ in ability to confer a second phenotype (such as ability to metabolize X-gal to a blue compound).

This exercise will also demonstrate a second important principle of DNA manipulation: when two genes are both present on the same DNA fragment, selection for one of the genes will force maintenance of the second gene as well. As the transformed bacteria grow and form colonies in the presence of ampicillin but in the absence of tetracycline, there is no selective pressure that requires the expression of the tetracycline resistance gene present on pBR322. Nevertheless, because the tetracycline resistance gene is part of pBR322, growth in the presence of ampicillin forces the maintenance of pBR322 and also selects for the covalently attached tetracycline resistance gene. If the blue and white colonies obtained on the ampicillin plate containing X-gal and IPTG are transferred to a nutrient plate containing tetracycline at a concentration of $20 \mu \mathrm{g} / \mathrm{ml}$, the blue colonies containing pUC19 will be unable to grow and the white colonies containing pBR322 will be able to form colonies. This is the fundamental principle that allows a plasmid or a viral DNA molecule to be used as a vector to carry and propagate exogenous, or extra, DNA fragments. DNA fragments that are covalently inserted into a vector by the use of restriction enzymes and DNA ligase will be maintained as the carrier vector molecule replicates in a host cell.

\section{Materials}

- Three nutrient agar plates containing $100 \mu \mathrm{g} / \mathrm{ml}$ ampicillin (NA+Ap plates).

- One nutrient agar plates containing $20 \mu \mathrm{g} / \mathrm{ml}$ tetracycline (NA+Tc plates).

- A water bath or temperature block at $43^{\circ} \mathrm{C}$.

- Incubator for plate culture (this can be performed at room temperature, but growth of colonies will take two days).

- Glass spreader bar.

- Ethanol or isopropanol for sterilizing glass spreader bar.

- One $0.2 \mathrm{ml}$ tube of competent JM83 (store these in a normal freezer [not frost-free if possible] until needed, then on ice).

- $\quad$ Ten $\mu \mathrm{l}$ of pUC19/pBR322 mixed plasmid DNA at 100 $\mu \mathrm{g} / \mathrm{ml}$.

- $2 \% X$-gal in dimethylformamide (this solvent is necessary for $\mathrm{X}$-gal).

- 100 mM IPTG in sterile water.

- $\quad$ Sterile toothpicks.

\section{Procedure}

1. Since X-gal and IPTG are not usually added to nutrient plates when the plates are liquid, it will be necessary to add these compounds to the surface of the solid plates prior to use. Place $0.1 \mathrm{ml}$ of the X-gal in a 1.5 $\mathrm{ml}$ microcentrifuge tube (not a polystyrene tube - the X-gal solvent may melt the plastic). Add $20 \mu$ l of IPTG to the tube and mix the two solutions to make an Xgal/IPTG mixture. 
2. Place $60 \mu \mathrm{l}$ of the X-gal/IPTG mixture on the surface of each of two of the plates containing ampicillin $(N A+A p)$. Save one NA+Ap plate and the NA+Tc plate for later use. Dip a glass spreader in alcohol and then ignite the alcohol in a burner flame to sterilize the spreader. Cool the spreader by touching the agar surface, then spread the X-gal/IPTG evenly across the surface of one of the NA+Ap plates. Again sterilize the spreader and spread the X-gal/IPTG mixture on the second $\mathrm{NA}+\mathrm{Ap}$ plate. Invert the plates and label "+Xgal/IPTG". This step allows the coloring agents to soak into the surface of the agar. The agar surface may cloud as the dimethylformamide solvent dissipates and the X-gal precipitates. It is important to add the Xgal/IPTG mixture shortly before the plates are used because the X-gal can break down and may not color well if too old.

3. Place a tube of competent cells on ice and allow to thaw. Add the $10 \mu \mathrm{l}$ of mixed plasmid DNA into the thawed cells and gently mix in. Return the cells to the ice.

4. Allow the tube to stand in the ice bucket for 15 to 20 minutes to allow the DNA to stick to the surface of the competent cells.

5. To make the DNA enter the cells, place the tube in a $43^{\circ} \mathrm{C}$ water bath (be careful with the temperature, too hot or too cool will not work as well). Allow the tube to incubate at $43^{\circ} \mathrm{C}$ for 60 seconds, then remove from the water bath and place at room temperature.

6. The transformation is complete. It is now necessary to plate the transformation mix on selective plates to detect the transformants and inhibit the growth of the non-transformed cells. Transfer $20 \mu \mathrm{l}$ of the transformed cells to one nutrient plate containing ampicillin, IPTG, and X-gal. Use a sterile spreader to distribute the cells. Label the plate " $20 \mu \mathrm{l}$ ". Spread the remainder of the transformed cells on the second plate and distribute uniformly with a sterile spreader. Label the plate " $180 \mu l$ ".

7. Incubate the plates overnight at $37^{\circ} \mathrm{C}$ to allow growth of colonies. Check the plates for colonies after 18 hours growth and transfer the plates to a refrigerator for storage if the colonies are sufficiently large (the size of a typewritten"o") or are extremely numerous (>300 per plate). Although the colonies will stop increasing in size, blue color will continue to develop in the cold. If allowed to remain at $37^{\circ} \mathrm{C}$ too long, non-transformed, ampicillin-sensitive "feeder" colonies will begin to form as the ampicillin-resistant colonies degrade the ampicillin in the medium.

8. If the transformation has been successful, both blue and white colonies should be present on the surface of the two plates. The blue colonies are formed as a result of the transformation of bacteria with pUC19 and the white colonies are formed as a result of the transformation of bacteria with pBR322. This can be verified by using the ability of pBR322 to allow growth in the presence of tetracycline. To check transformants for this phenotypic property, label the back of the remaining $N A+A p$ plate and the $N A+T c$ plate with the numbers " 1 " to " 40 " and your initials as indicated below:

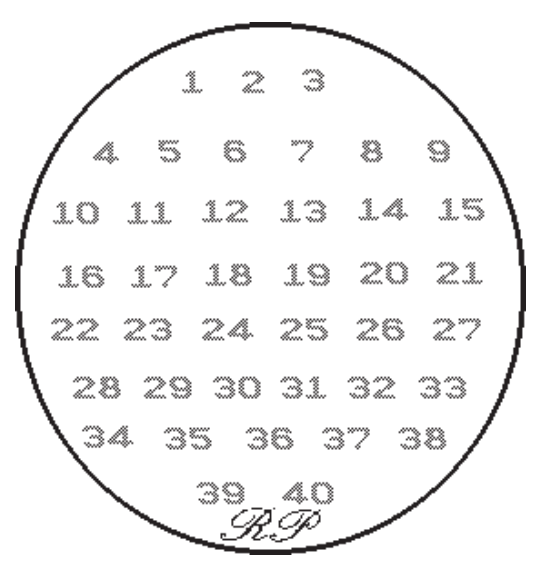

9. Touch a sterile toothpick to a blue colony on one of the NA+Ap X-gal/IPTG plates and make a short streak of cells over the number " 1 " on the NA+Ap plate and the NA+Tc plate. Repeat this for an additional 19 blue colonies and for 20 white colonies. Incubate both plates overnight at $37^{\circ} \mathrm{C}$ to allow the growth of the bacteria.

\section{Analysis and significance of results}

Since both the blue and the white colonies were originally obtained following growth on an NA+Ap X-gal/IPTG plate, all of these colonies should again grow on the NA+Ap plate but, since X-gal and IPTG are no longer present, all colonies should remain white. Only the white colonies obtained from the NA+Ap X-gal/IPTG plate should form colonies on the $\mathrm{NA}+\mathrm{Tc}$ plate, confirming that the transformants that originally formed white colonies on NA+Ap X-gal/IPTG contained pBR322. Note that although the original selection for transformed bacteria involved resistance to ampicillin, resistance to tetracycline was also maintained by nearly all of the ampicillin-resistant white colonies. Since the genes conferring resistance to ampicillin and tetracycline are both present on the same DNA molecule (the plasmid pBR322), selection for one of the two genes (ampicillin resistance) also selects for the presence of the non-selected gene (tetracycline resistance).

It is possible to obtain ampicillin-resistant white colonies that cannot grow on tetracycline and ampicillinresistant blue colonies that can grow on tetracycline. When the DNA from the plasmids present in these colonies is isolated and examined by digestion with restriction enzymes, the first type of colony can often be demonstrated to be caused by the occurrence of a deletion that removes part or all of the B-galactosidase gene of pUC19, causing inability to metabolize X-gal to a blue compound, or a deletion that removes part of the tetracycline resistance gene, causing loss of tetracycline resistance. These deletions occur naturally in bacteria as an aspect of normal DNA replication, recombination, and repair processes.

The second type of colony is most commonly caused by the presence of bacteria containing both pUC19 and pBR322 in the same colony. This can be verified by streaking the bacteria out on an NA+Ap X-gal/IPTG plate and incubating to obtain isolated colonies that are either blue and tetracycline-sensitive or white and tetracyclineresistant. While both plasmids can occassionally be inserted into the same bacterial cell during the transformation process, pUC19 and pBR322 replicate by very similar mechanisms and are said to be incompatible 
with one another. When incompatible plasmids are inserted into the same bacterium and the cell is grown in the absence of selective pressure designed to force maintenance of both plasmid types, the plasmids will segregate during division of the transformed bacterium and the resulting progeny will contain one or the other of the two plasmids.

\section{Exercise 6. Comparison of plasmid and bacteriophage cloning vectors}

Much of the scientific utility of recombinant DNA technology is based on the use of self-replicating DNA elements to serve as carriers for DNA fragments that are not capable of replication in bacteria. Bacterial cloning vectors are based on either bacterial plasmids or bacteriophage. Plasmids are naturally occurring, circular DNA molecules that can replicate as mini-chromosomes in bacteria. When isolated from nature, these DNA molecules also generally encode resistance to one or more antibiotics and may contain genes that allow transfer of the plasmid DNA from one cell to another during bacterial mating. Most cloning vectors derived from plasmids retain the plasmid origin of DNA replication and one or more antibiotic resistance genes, such as the B-lactamase gene, which allows sensitive bacteria to form colonies on solid medium containing ampicillin. With plasmid cloning vectors, selection of bacteria containing the vector requires selection for a phenotype, or physical characteristic, associated with a gene present on the vector DNA molecule.

Cloning vectors have also been constructed from bacteriophage, viruses that replicate in bacteria. Two types of bacteriophage cloning vectors, derived from either the double-stranded, linear DNA bacteriophage lambda or the malespecific, single-stranded, circular DNA bacteriophage $\mathrm{M} 13$, are in common use in E. coli. Detection of cells containing either of these types of vector does not require selection for a phenotypic marker, but is based on the ability of the bacteriophage to form a plaque in a lawn of host bacteria, a property associated with the replication of the viral DNA vectors.

Lambda has a large genome (approx. 50 kilobase pairs of double-stranded DNA) that can, on insertion into a bacterial host, activate either of two sets of viral genes. One set of genes allows the bacteriophage to undergo a lytic cycle during which progeny phage are produced and the infected bacterial cell bursts open, releasing the daughter phage into the medium. When activated, the other set of genes causes the bacteriophage DNA to lysogenize, or insert itself into a specific location in the bacterial genomic DNA, where it remains silent while the bacterial cell undergoes normal cellular functions. Certain conditions, such as DNA damage, will induce the lysogen, activating the lytic genes. The bacteriophage DNA then excises from the host chromosome, produces progeny, and lyses the host cell. When bacteria are grown on the surface of solid medium from a low density to a uniform lawn of cells, the presence of lambda can be detected by the appearance of plaques, circular clear zones in the cloudy lawn of host bacteria. As the host bacteria grow to form the indicator lawn, successive cycles of infection/production of progeny/ cell lysis cause the death and lysis of all of bacteria in a circular zone surrounding even a single lambda bacteriophage. Cells that are able to lysogenize the lambda
DNA into their own genome become resistant to infection and may form small colonies within the zone of lysis. The ability of lambda DNA to cause the lysis of bacteria serves as the selective marker for the presence of cloning vectors derived from this bacteriophage. In marked contrast to plasmid cloning vectors, which require phenotypic selection to detect cells containing the vector, the replication of a lambda cloning vector provides a plaque, the immediate means of detection of cells containing the vector. Because the lambda plaque is basically a zone of lysed cells, however, the plaque indicates only where the infected cells were. Lambda vectors and recombinants derived from them must generally be maintained not as viable bacterial strains, but as stocks of virus particles.

An M13 bacteriophage particle contains a singlestranded, circular DNA genome of about 8 kilobase pairs. These particles will only infect host bacteria that are producing the F-pilus protein, which is part of the mating apparatus encoded by the large $\mathrm{F}$ plasmid. Bacteria that are male, or $\mathrm{F}^{+}$, can be infected by the $\mathrm{M} 13$ phage particle. The entering single-stranded viral DNA is converted to and replicates as a double-stranded circular DNA. Singlestranded progeny phage identical to the original infecting DNA are produced, coated with viral coat proteins, and extruded through the bacteria cell wall into the medium without lysing the host cell. When propagated in a sensitive host grown on the surface of a solid medium, cloning vectors derived from M13 will form small, circular zones of infected cells that are extruding phage particles. In contrast to plaques formed by lambda vectors, these plaques are cloudy rather than clear and contain viable, infected cells that can be propagated as bacterial strains. While these plaques are biologically quite different than those induced by strains of lambda, the plaques appear similar to those induced by lambda. M13 vectors and recombinants derived from them can be maintained as either viable infected bacteria containing the double-stranded circular replicating form of virus DNA or as stocks of viral particles containing single-stranded circular DNA.

This exercise will use $\mathrm{JM} 101$, an $\mathrm{F}^{+}$strain of $E$. coli that will allow growth of plasmids and M13 to illustrate the similarities and differences in the use of these different types of cloning vector.

\section{Materials}

- Six tubes competent JM101 bacteria.

- $\quad 11 \mu \mathrm{l}$ pUC19 DNA, $100 \mu \mathrm{g} / \mathrm{ml}$ (Amp ${ }^{r}$ plasmid vector).

- $11 \mu \mathrm{lmp} 19 \mathrm{DNA}, 100 \mu \mathrm{g} / \mathrm{ml}$ (M13 cloning vector).

- Two LB plates containing $100 \mu \mathrm{g} / \mathrm{ml}$ ampicillin (LBAp).

- Two LB plates (LB).

- Twenty-five ml LB-soft agar (LB containing $0.8 \%$ agar).

- $\quad$ Sterile $5-10 \mathrm{ml}$ glass or plastic tubes.

\section{Procedure}

1. Place the tubes of competent cells in an ice bucket to thaw. Label the two LB-Ap plates "pUC19 $1 \mu \mathrm{l}$ " and "pUC19 $10 \mu \mathrm{l}$ ". Label two LB plates "mp19 $1 \mu \mathrm{l}$ " and "mp19 $10 \mu \mathrm{l}$ ". Leave the plates at room temperature to warm up for about 10 minutes.

2. When the competent cells have thawed, label the tubes as below: 
Tube 1

Tube 2

Tube 3

Tube 4

pUC19 $1 \mu \mathrm{l}$

pUC19 $10 \mu \mathrm{l}$

$\operatorname{mp} 191 \mu \mathrm{l}$

$\operatorname{mp} 1910 \mu \mathrm{l}$

3. Add the appropriate amount of each of the DNA samples to the labeled tubes of competent cells and gently mix in. Allow to incubate on ice for 20 minutes.

4. Label four of the capped sterile glass or plastic tubes as below:

$\begin{array}{ll}\text { Tube 1 } & \text { pUC19 } 1 \mu \mathrm{l} \\ \text { Tube 2 } & \text { pUC19 10 } \mu \mathrm{l} \\ \text { Tube 3 } & \mathrm{mp} 191 \mu \mathrm{l} \\ \text { Tube 4 } & \mathrm{mp} 1910 \mu \mathrm{l}\end{array}$

5. Use a microwave or boiling water bath to melt the 25 $\mathrm{ml}$ of LB-soft agar. Place the melted soft agar in a $55^{\circ} \mathrm{C}$ bath for at least 5 minutes to allow the temperature to decrease from boiling. Use a sterile pipet to dispense $3 \mathrm{ml}$ of the liquid agar into the tube labeled "Tube 1 pUC19 $1 \mu \mathrm{l}$ ". Immediately use a pipet device and sterile tip to transfer the competent cell/DNA mixture in the tube labeled "pUC19 $1 \mu$ " into the $3 \mathrm{ml}$ of liquid agar. Pour the mixture onto the surface of the LB-Ap plate labeled "pUC19 $1 \mu \mathrm{l}$ " and gently rotate the plate to distribute evenly over the surface of the plate. Carefully place the overlaid plate aside to solidify and do not move it for $\mathbf{5}$ minutes. If this process is too slow, the agar will solidify in the tube or in lumps on the surface of the plate. If the overlaid plate is inverted too soon after the pouring process, the soft agar will slide off of the agar plate.

6. Repeat this overlay for each of the remaining tubes of competent cells.

7. Incubate the plates at $37^{\circ} \mathrm{C}$ to allow growth of the bacteria.

\section{Analysis of results}

Following $12-18$ hours of incubation at $37^{\circ} \mathrm{C}$, the bacteria will have grown sufficiently to compare the difference in the two types of vectors. For the cells transformed with pUC19, the ampicillin in the LB plate rapidly diffuses into the soft agar overlay and retards the growth of the nontransformed cells. Cells that contain the plasmid are resistant to the antibiotic and form small colonies in and on the surface of the soft agar overlay.

For each of the bacteriophage vector transformations, the non-transformed bacteria will have formed a fairly uniform layer of cells called a lawn. The M13 mp19 vector will cause numerous holes and depressions in the lawn. These are best viewed by holding the plate up to a bright light.

Note that as the size of the vector increases, the number of transformants decreases (\# pUC>\# mp19). This is principally caused by the difference in the sizes of these vectors (about $3 \mathrm{~kb}$ and $8 \mathrm{~kb}$ ).

\section{Exercise 7. The miniscreen: Rapid isolation of plasmid DNA}

The construction of a library of recombinant plasmids involves the digestion of chromosomal and vector DNA with a restriction enzyme, followed by joining chromosomal
DNA fragments to the linearized vector DNA with the enzyme T4 DNA ligase, followed by insertion of the DNA into a host cell. Because the presence of restriction enzymes can interfere with the ligation process, the digested DNA samples are generally extracted with phenol/ chloroform to remove protein. Then, because ligation activity is not optimal in the buffer used for restriction of the DNA's, samples are precipitated with ethanol, washed with $70 \%$ ethanol to remove salts, dried, and resuspended in ligation buffer. The enzyme T4 DNA ligase, which uses ATP as a co-factor, is added to seal the nicks in the DNA molecules and generate recombinant molecules. The ligated DNA sample can then be used to transform competent cells to give blue and white colonies.

The blue and white colonies obtained after transformation of cells with a ligated DNA sample can be cultured and the plasmid DNA present in the cells extracted and examined. When purifying circular plasmid DNA from a bacterial cell, it is necessary to separate the plasmid away from the chromosomal DNA. Differences in the physical properties of these two types of DNA facilitate this separation. While purification of large (milligram) amounts of plasmid can be somewhat time-consuming and involve the use of large cultures (typically 1 liter) of bacteria, a variety of rapid isolation procedures allow the purification of a small amount of plasmid DNA (1- $5 \mu \mathrm{g})$ from a small culture $(1-10 \mathrm{ml})$. The DNA obtained by these small-volume, rapid-isolation methods, generally referred to as "miniscreens" or "minipreps", is not as pure as that obtained by more elaborate methods, but is suitable for many characterization and cloning procedures.

These miniscreen procedures arose from the need to quickly sort through a number of bacterial transformants that contained recombinant DNA molecules of potential interest. A typical gene isolation experiment might generate 20 candidates for the desired gene construction. The time, expense and labor involved in purifying the DNA from a 1 liter culture of each candidate were found to be quite annoying, and abbreviated protocols were developed to allow the simultaneous screening of many candidates.

Rapid miniscreen procedures take advantage of the different purification properties of chromosomal DNA and supercoiled plasmid DNA to obtain a partial purification of the plasmid from a small culture. Steps of the process are generally performed in $1.5 \mathrm{ml}$ plastic tubes, and centrifugation is in a microcentrifuge that can spin 12-24 tubes at 12,000 to 16,000x gravity. Spins used to remove precipitates are on the order of 5-15 minutes, and the entire miniscreen process will take about 90 minutes to purify the plasmid DNA from 12 samples. These protocols facilitate both the mass screening of transformants containing DNA molecules of potential interest and the rapid analysis and manipulation of DNA samples of particular interest.

Following transformation of JM83 with the pUC19:E. coli library DNA, incubation of the LB-Ap plates for 12-18 hr should result in the formation of bacterial colonies on the surface of the plates. Those transformants that contain only pUC19 are both $\mathrm{Ap}^{r}$ and able to metabolize X-gal to a blue compound and form blue colonies, while those cells that contain pUC19 plasmids with DNA inserts are Ap ${ }^{r}$ but unable to metabolize X-gal and therefore form white colonies. The ratio of white to blue colonies is an indicator of the frequency of recombinant transformants in the population. 
To characterize the plasmids in the recombinant transformants, white colonies are picked with a sterile loop and transferred into $2 \mathrm{ml}$ cultures of LB medium, allowed to grow for $6-18 \mathrm{hr}$ at $37^{\circ} \mathrm{C}$ with shaking, then subjected to a miniscreen procedure. These cultures can either be inoculated the day before needed or grown several days in advance and stored in a refrigerator until needed. Long term storage of cells for DNA extraction is best accomplished by harvesting the cells from the cultures (step 1 below), adding the SET buffer, and freezing the cell pellets. To proceed with the miniscreen, thaw the pellets and vortex to resuspend the cells, then resume with step 3.

\section{Materials}

- LB medium: 1\% Bacto Tryptone, 0.5\% Bacto Yeast Extract, $0.5 \% \mathrm{NaCl}, \mathrm{pH} 7.0-7.2$ (sterilized) for propagation of cultures to be miniscreened. Any complete nutrient medium can be substituted.

- One $2 \mathrm{ml}$ LB E. coli JM83 culture, grown at $37^{\circ} \mathrm{C}$ with shaking for 8-15 hours.

- One $2 \mathrm{ml}$ LB E. coli JM83 culture containing the plasmid pUC19, grown at $37^{\circ} \mathrm{C}$ with shaking for 8-15 hours.

- Four $2 \mathrm{ml}$ LB E. coli JM83 cultures from white recombinant colonies obtained from the pUC19:E. coli library, grown at $37^{\circ} \mathrm{C}$ with shaking for $8-15$ hours.

- SET buffer: $20 \%$ sucrose, 50 mM TRIS-HCI pH 7.6, $50 \mathrm{mM}$ EDTA.

- $\quad$ Lytic mix: $1 \%$ SDS, $0.2 \mathrm{~N} \mathrm{NaOH}$.

- $\quad$ Sodium (Na) acetate: $3.0 \mathrm{M}, \mathrm{pH}$ 4.8. Make $3 \mathrm{M}$ acetic acid and $3 \mathrm{M} \mathrm{Na}$ acetate, then mix to $\mathrm{pH} 4.8$. If not made this way, miniscreens will not necessarily work well. Store at $4^{\circ} \mathrm{C}$.

- RNase stock: Pancreatic ribonuclease A (RNase A), 1 $\mathrm{mg} / \mathrm{ml}$ in $0.1 \mathrm{M}$ sodium acetate, $0.3 \mathrm{mM}$ EDTA.

- Isopropanol: Room temp.

- Ethanol: $70 \%$, room temp. (70\% isopropanol can be substituted).

- Water $\left(\mathrm{dH}_{2} \mathrm{O}\right)$ : Sterile, deionized or distilled.

- Ice.

- Conical microcentrifuge tubes and pipet tips.

\section{Protocol}

1. Transfer $1.5 \mathrm{ml}$ of each culture to a labeled microcentrifuge tube. You should have a total of six tubes. Spin $1 \mathrm{~min}$ to pellet cells. Pour off and discard supernatants.

2. Resuspend cell pellets in $150 \mu \mathrm{l}$ of SET buffer. Vortex or agitate to resuspend cells.

3. To each tube add $350 \mu \mathrm{l}$ of Lytic mix. Invert several times to mix. Cells will lyse and solution will clear slightly. Viscosity increases.

4. Place in ice bath and chill approx. 10 min. Solution will begin to cloud as SDS precipitates.

5. To each tube, add $250 \mu \mathrm{l}$ of cold $\mathrm{Na}$ acetate buffer. Invert to mix. Return tubes to ice bath and incubate 15 min. SDS and chromosomal DNA will precipitate during this incubation.

6. Centrifuge tubes $10 \mathrm{~min}$ at $4^{\circ} \mathrm{C}$ in a microcentrifuge. Pour supernatants (approx. $700 \mu \mathrm{l}$ ) into clean, labeled microcentrifuge tubes. Discard tubes containing the pellets.

7. To each tube containing a supernatant, add $2 \mu$ of
RNase stock. Invert to mix. Incubate $10 \mathrm{~min}$ at $37^{\circ} \mathrm{C}$.

8. Add an equal volume (approx. $700 \mu \mathrm{l}$, simply fill the remainder of the space in the tube) of isopropanol. Invert tubes several times to mix. Immediately centrifuge $5 \mathrm{~min}$ at room temp in a microcentrifuge. Pour off and discard supernatants.

9. Wash DNA pellets by adding $1 \mathrm{ml}$ of $70 \%$ ethanol to each tube. Invert several times to mix. Centrifuge 3 min at room temp. Pour off ethanol and use a Kimwipe to dry the lip of each tube. Vacuum dry the DNA pellets. Resuspend each pellet in $20 \mu \mathrm{d}_{2} \mathrm{O}$. After DNA has been allowed to resuspend for 10 minutes on ice, tap the tubes gently to help resuspend the DNA, then centrifuge 20 seconds to collect solution in the bottom of the tubes. The DNA is now ready to be digested with restriction enzymes or can be stored frozen until further use.

\section{Flow chart, Exercises 7 and 8}

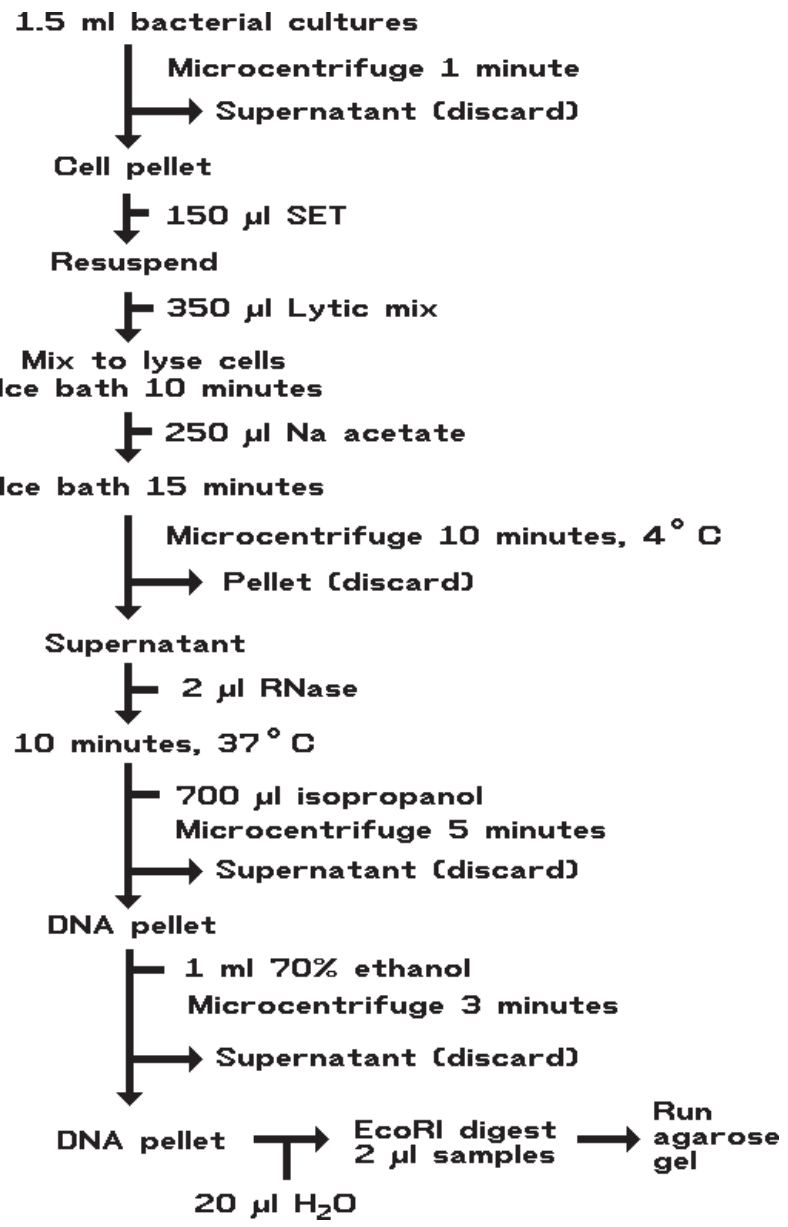

\section{Exercise 8. Characterization of pUC19 recombinant DNAs}

The miniscreen DNAs will now be digested with restriction endonuclease $\mathrm{EcoRI}$, the same enzyme that was used to construct the library. Any DNA fragments that were inserted in the unique EcoRI site of pUC19 will be released upon digestion, and agarose gel electrophoresis will allow characterization of the size and number of additional fragments. 


\section{Materials}

- Miniscreen DNAs.

- Ice.

- Conical microcentrifuge tubes and pipet tips.

- $\quad$ Endonuclease digestion materials, see Exercise 2.

- Gel electrophoresis materials, see Exercise 1.

\section{Protocol}

1. If you plan to digest more than a few samples, it is convenient to make a mix containing 10x EcoRI buffer, $\mathrm{H}_{2} \mathrm{O}$, and $E c o R I$ enzyme, aliquot this mix into reaction tubes, then to each tube add a separate DNA sample. For example, for each six miniscreens to digest, plan on a $20 \mu \mathrm{l}$ reaction for each digest, with $2 \mu \mathrm{l}$ of miniscreen DNA diluted into $18 \mu \mathrm{l}$ of reaction mix. Prepare the following mix:

$\begin{array}{ll}\text { 10x EcoRl buffer } & 12 \mu \mathrm{l} \\ \mathrm{dH}_{2} \mathrm{O} & 96 \mu \mathrm{l} \\ \text { EcoRl enzyme, 20 units } & 2-5 \mu \mathrm{l} \\ \text { Total volume } & 110-113 \mu \mathrm{l}\end{array}$

Label six tubes for the digestion reactions, and dispense $18 \mathrm{ul}$ of this mix into each tube. Then add 2 $\mu \mathrm{l}$ of a miniscreen DNA to each of the tubes, for a total of six different reactions. This is more convenient than setting up six individual reactions.

2. Incubate at $37^{\circ} \mathrm{C}$ for $30-60 \mathrm{~min}$, then remove $8 \mu \mathrm{l}$ from each digestion and place on a Parafilm strip. Add $3 \mu \mathrm{l}$ of SM dye to each sample.

3. Subject samples to electrophoresis on a $1 \%$ agarose gel in TBE buffer. Run a sample of EcoRI- or HindIIIdigested lambda DNA as a molecular weight standard.

4. Following electrophoresis, staining and visualization of the DNA fragments will reveal any additional fragments present in the pUC19 recombinants. While a photographic record of the gel allows convenient measurement of fragment position for the purpose of calculating mobilities, and hence determining molecular weights, photos are expensive. A ruler can be laid next to the gel on the UV box, and a drawing with measurements added used to construct a graph of fragment mobilities.

\section{Analysis and significance of results}

A considerable amount of sample variability is common when learning to prepare miniscreen DNA. A typical gel with good quality DNA is illustrated below:

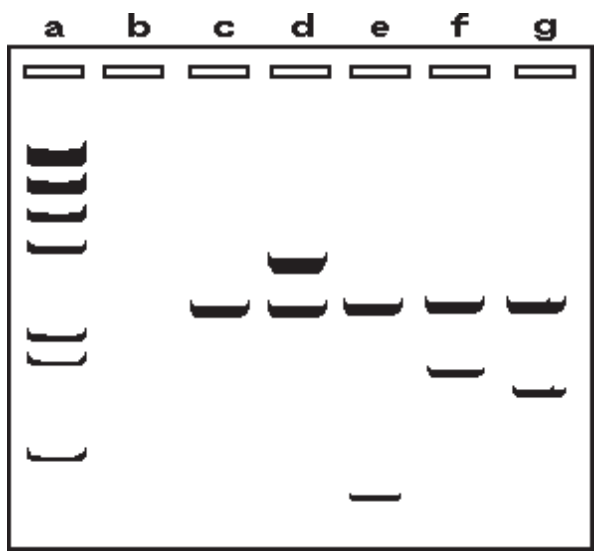

Lane a. HindlII lambda DNA

Lane b. JM83 (no plasmid)

Lane c. JM83 (pUC19)

Lane d. JM83 (recombinant \#1)

Lane e. JM83 (recombinant \#2)

Lane f. JM83 (recombinant \#3)

Lane g. JM83 (recombinant \#4)

Note that no specific DNA fragments other than a faint background of chromosomal DNA fragments are observed in the miniscreen DNA prepared from the JM83 culture containing no plasmid, while the five samples prepared from $\mathrm{Ap}^{r}$ transformants all contain specific DNA bands. This further demonstrates that the presence of the plasmid DNA in the transformants is associated with the conversion to ampicillin resistance. In addition, the presence of inserted DNA fragments correlates with the inability of recombinant pUC19 plasmids to generate blue transformant colonies. Different recombinant colonies may contain inserts of different sizes. Small inserts may not be detected by agarose gel electrophoresis.

Many of the gel artefacts commonly associated with miniscreen DNA are illustrated below:

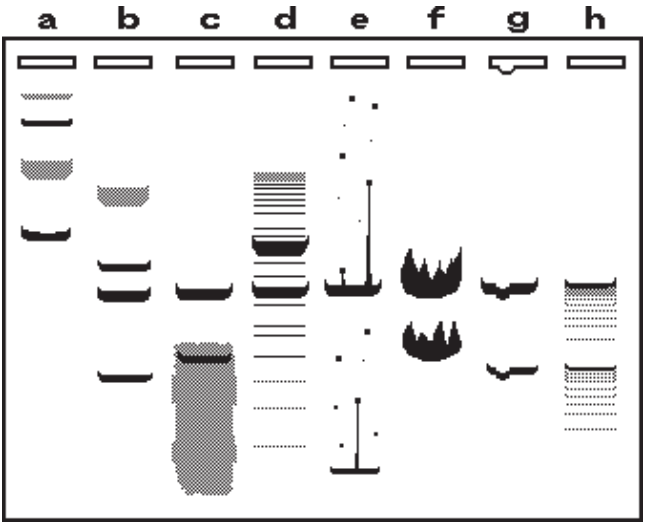

Lane a. Undigested DNA with both supercoiled (dark bands) and open circular (stippled bands) forms.

Lane b. Partially digested plasmid DNA sample with insert (bottom band), plasmid vector (second from bottom), linear recombinant cut at only one of two cleavage sites (third from bottom), and open circular DNA (stippled band).

Lane c. Digested plasmid DNA sample containing undigested RNA (stippled region).

Lane d. Digested plasmid DNA sample contaminated with digested bacterial chromosomal DNA not eliminated during the DNA preparation.

Lane e. Unmelted agarose specks causing DNA streaking and spots in the gel.

Lane f. Too much DNA loaded in the lane causing distortion of bands.

Lane g. Bubble in sample well deforming DNA bands.

Lane $h$. Digested DNA sample degraded by contaminating exonuclease or endonuclease.

\section{Exercise 9. DNA fingerprinting}

The ability to digest DNA fragments, separate these fragments according to size, and detect fragments containing specific genes has led to a genetic identification 
approach called DNA fingerprinting. This method takes advantage of the fact that a single nucleotide sequence difference can cause the appearance or disappearance of a restriction enzyme cleavage site in DNA. The individualspecific differences in restriction enzyme cleavage site position relative to a specific gene can cause variation in the size of the DNA restriction fragment that carries that gene in different individuals. The variation in the size of a restriction fragment that carries a specific gene, referred to as "restriction fragment length polymorphism" (RFLP), can be used to genetically match DNA samples with the donors from which they were obtained. Individuals who appear identical for a specific physical trait can be easily distinguished if sequence differences that cause changes in DNA restriction fragment sizes are associated with that trait

When applied to identification of human DNA samples, DNA fingerprint analysis is complicated by the presence of hundreds or thousands of DNA fragments following digestion of DNA samples with a specific restriction enzyme. Rather than attempt to analyze all of the DNA fragments, the fragments are generally separated by gel electrophoresis, transferred to a membrane, and allowed to react with a DNA or RNA hybridization probe that will specifically anneal to a small number of the many different DNA fragments. The probe fragment generally contains a nucleoside that is either radioactive (such as ${ }^{32} \mathrm{PdATP}$ ) and can be detected by autoradiography or has been modified (such as biotinylated dATP) to be recognized by specific antibodies and detected by a color reaction. The image that is obtained by visualization of the probe is a subset of the total set of DNA fragments and can be referred to as a DNA fingerprint. When hybridization probes are chosen carefully, the fingerprints can be specific for DNA that has been found to have a high degree of individual-specific variation. When sufficient information has been obtained about the frequency of occurence of a specific DNA fingerprint pattern, the DNA fingerprints of two DNA samples can be used to calculate the probability of whether the two DNA samples were obtained from the same individual.

Since humans are diploid and contain two copies of each chromosome, one from the mother and the other from the father, a human DNA fingerprint can be thought of as the combination of two fingerprint patterns. Since these patterns can be used to link an "unknown" DNA sample to DNA samples obtained from specific individuals, DNA fingerprint analysis is becoming increasingly common as courtroom evidence in paternity suits and in criminal prosecution involving crimes like rape and murder. This exercise will use bacteriophage lambda DNA digested with various restriction enzymes to simulate the results of a DNA fingerprint analysis and help determine paternity of a child.

\section{Materials}

Bacteriophage lambda DNA at a final concentration of 50 $\mu \mathrm{g} / \mathrm{ml}$ in gel loading buffer, digested with the following restriction enzymes: HindIII (H), EcoRI (E), BamHI (B), Kpnl $(\mathrm{K})$, and Sall $(\mathrm{S})$. Each of these digests will be used to simulate a haploid DNA fingerprint (one set of chromosomes). To make the test DNA samples obtained from the individuals involved in the paternity suit, the digested lambda DNA samples have been mixed in the following manner to simulate the diploid chromosomal fingerprint of each individual:

$\begin{array}{ll}\text { Mother } & =100 \mu \mathrm{lH}+100 \mu \mathrm{l} \mathrm{H} \\ \text { Baby } & =100 \mu \mathrm{H}+100 \mu \mathrm{l} \mathrm{E} \\ \text { Rock Star } & =100 \mu \mathrm{H}+100 \mu \mathrm{K} \\ \text { Ex-drummer } & =100 \mu \mathrm{I}+100 \mu \mathrm{l} \\ \text { Mailman } & =100 \mu \mathrm{S}+100 \mu \mathrm{l} \mathrm{E}\end{array}$

Loading $7 \mu \mathrm{l}$ of each mix will deliver 350 ng of DNA, giving distinctive diploid DNA fingerprint patterns for each individual.

- Gel box, gel tray and comb.

- Power supply.

- UV light source.

- Dry agarose.

- $10 \mathrm{mg} / \mathrm{ml}$ ethidium bromide.

- 10X TBE gel buffer.

\section{Background}

While living with a rock star, a young woman becomes pregnant, whereupon the rock star promptly severs his relationship with the woman, leaving her and the resultant baby completely penniless. The mother of the child sues for child support, claiming the rock star as the father of her baby. The following are the summary statements from each of the individuals who become involved in the resulting paternity suit:

Mother: $\quad$ Rock Star is the father of my baby. He should be required to financially support us.

Baby: Wah! Burp.

Rock Star: The child is not my son. The males in my family were found through genetic analysis to carry a recessive gene that causes incurable craving for disco music. On the advice of my doctor, I had a vasectomy when I was twenty-three to prevent transmission of this genetic disorder to my children. I kicked her out because I caught her in bed with my Drummer, not because she was pregnant. She should talk to him about support.

Ex-drummer: Who says I'm the father? I wasn't the only other guy she was seeing. I even caught the mailman in the bedroom with her. I couldn't support her anyways. I can't get work since Rock Star kicked me out of his band and I got busted with 2 pounds of heroin.

Mailman: Sure I was in her bedroom. I had a package for Rock Star and needed a signature. When I rang the doorbell, she called out she was sick in bed, but the door was unlocked and she would sign for the package if I didn't mind risking the flu. I was leaving her bedroom when Drummer walked in the front door. I think the door was unlocked and she was in bed waiting for Drummer.

At the request of the court, DNA is extracted from blood samples obtained from each of these individuals and provided to you, who will perform the fingerprint analysis and interpret the results. 


\section{Procedure}

1. Weigh out 0.5 gram of the agarose and place in a 100 $\mathrm{ml}$ flask or beaker. Add $45 \mathrm{ml}$ of distilled water and 5 $\mathrm{ml}$ of 10X TBE buffer.

2. Melt the agarose completely in a microwave oven or boiling water bath. The solution must boil to melt the agarose. Agarose has a tendency to superheat and flash-boil, so be careful on the first boiling. The boiling will be more controlled once some of the agarose has melted. Be certain all the small particles are melted to prevent streaks in the gel. The agarose should be allowed to cool to about $55^{\circ} \mathrm{C}$. It will solidify at about $45^{\circ} \mathrm{C}$.

3. Add $2 \mu$ l of ethidium bromide to the agarose and mix. This is the stain to detect the DNA. Ethidium bromide is a mutagen (comparable to a pack of cigarettes) and solutions containing ethidium should not be handled with bare hands.

4. Pour a gel as demonstrated and allow to solidify.

5. Assemble the gel in the gel box. Submerge the gel in 1X TBE running buffer made by diluting $10 \mathrm{ml}$ of $10 \mathrm{X}$ TBE Buffer with $90 \mathrm{ml}$ of distilled water.

6. Load the samples in the following order and amount:

\begin{tabular}{lll} 
Lane & DNA Sample & Amount \\
\hline 1 & Mother & $7 \mu \mathrm{l}$ \\
2 & Baby & $7 \mu \mathrm{l}$ \\
3 & Rock Star & $7 \mu \mathrm{l}$ \\
4 & Drummer & $7 \mu \mathrm{l}$ \\
5 & Mailman & $7 \mu \mathrm{l}$ \\
6 & Baby & $7 \mu \mathrm{l}$
\end{tabular}

7. Plug in the leads and turn on the power. Voltage of around 80 to 120 volts is typical, but will vary depending on the gel box. A very low voltage will slow the run down, but will enhance resolution of the DNA bands. A very high voltage will heat the buffer and can actually melt the gel. The depth of the buffer determines how much current flows in the system. Use only enough buffer to just submerge the gel to prevent excessive heating of the gel (deep buffer $=$ high current $=$ high heat production).

8. As the run progresses, two blue bands will resolve in the gel. These are merely tracking dyes to judge how far the DNA has migrated. When the faster dye is reaches the bottom of the gel, turn off the power. Remove the gel from the box and expose to the UV light. Be careful to shield eyes and skin from the UV light, as it is both a mutagen and a skin and eye burning agent.

9. Either photograph or sketch the resulting band patterns. Analyze the DNA band patterns. Remember that the DNA fingerprint of each person will contain two sets of bands, one from each parent. These could be either two identical sets of bands, as in the case of the Mother $(\mathrm{HH})$, or two different sets of bands, as in the case of the Baby (HE). The Mother must have obtained one $\mathrm{H}$ set of bands from her mother and one $\mathrm{H}$ set of bands from her father. The Baby must also have obtained one set of bands from its mother and one set from its father.
Questions you will need to consider:

1. Is Rock Star the father of the Baby? Why or why not?

2. Is Drummer the father of the Baby? Why or why not?

3. Is Mailman the father of the Baby? Why or why not?

4. The probability that a DNA fingerprint will contain a particular DNA band pattern is dependent on the frequency of that particular band pattern in the general population. You are now provided with the information that the entire population of the USA has been screened with the DNA probes you have just used and the frequencies of occurrence of the $\mathrm{H}, \mathrm{E}, \mathrm{K}, \mathrm{B}$, and $\mathrm{S}$ band patterns have been determined to be as follows:

$\begin{array}{ll}\text { Band pattern } & \text { Frequency in population } \\ \mathrm{H} & 1 \text { in } 100 \text { people } \\ \mathrm{E} & 1 \text { in } 10 \text { people } \\ \mathrm{K} & 1 \text { in } 100,000 \text { people } \\ \mathrm{B} & 1 \text { in } 100,000 \text { people } \\ \mathrm{S} & 1 \text { in } 50 \text { people }\end{array}$

Does this information change your answers to questions 1-3 above, and why or why not?

5. As the court-appointed expert in DNA fingerprints, what is your recommendation to the court regarding the paternity suit and the identity of the father of the Baby?

\section{Further Reading}

Tait, R.C. 1997. An Introduction to Molecular Biology. Horizon Scientific Press, Wymondham, UK. 


\section{Further Reading}

Caister Academic Press is a leading academic publisher of advanced texts in microbiology, molecular biology and medical research. Full details of all our publications at caister.com

- MALDI-TOF Mass Spectrometry in Microbiology Edited by: M Kostrzewa, S Schubert (2016) www.caister.com/malditof

- Aspergillus and Penicillium in the Post-genomic Era Edited by: RP Vries, IB Gelber, MR Andersen (2016) www.caister.com/aspergillus2

- The Bacteriocins: Current Knowledge and Future Prospects Edited by: RL Dorit, SM Roy, MA Riley (2016)

www.caister.com/bacteriocins

- Omics in Plant Disease Resistance Edited by: V Bhadauria (2016) www.caister.com/opd

- Acidophiles: Life in Extremely Acidic Environments Edited by: R Quatrini, DB Johnson (2016) www.caister.com/acidophiles

- Climate Change and Microbial Ecology: Current Research and Future Trend

Edited by: J Marxsen (2016)

www.caister.com/climate

- Biofilms in Bioremediation: Current Research and Emerging Technologies

Edited by: G Lear (2016)

www.caister.com/biorem

- Microalgae: Current Research and Applications Edited by: MN Tsaloglou (2016) www.caister.com/microalgae

- Gas Plasma Sterilization in Microbiology: Theory, Applications, Pitfalls and New Perspectives Edited by: H Shintani, A Sakudo (2016) www.caister.com/gasplasma

- Virus Evolution: Current Research and Future Directions Edited by: SC Weaver, M Denison, M Roossinck, et al. (2016) www.caister.com/virusevol

- Arboviruses: Molecular Biology, Evolution and Control Edited by: N Vasilakis, DJ Gubler (2016) www.caister.com/arbo

- Shigella: Molecular and Cellular Biology Edited by: WD Picking, WL Picking (2016) www.caister.com/shigella

-Aquatic Biofilms: Ecology, Water Quality and Wastewater Treatment

Edited by: AM Romaní, H Guasch, MD Balaguer (2016)

www.caister.com/aquaticbiofilms

- Alphaviruses: Current Biology

Edited by: S Mahalingam, L Herrero, B Herring (2016)

www.caister.com/alpha

- Thermophilic Microorganisms

Edited by: F Li (2015)

www.caister.com/thermophile
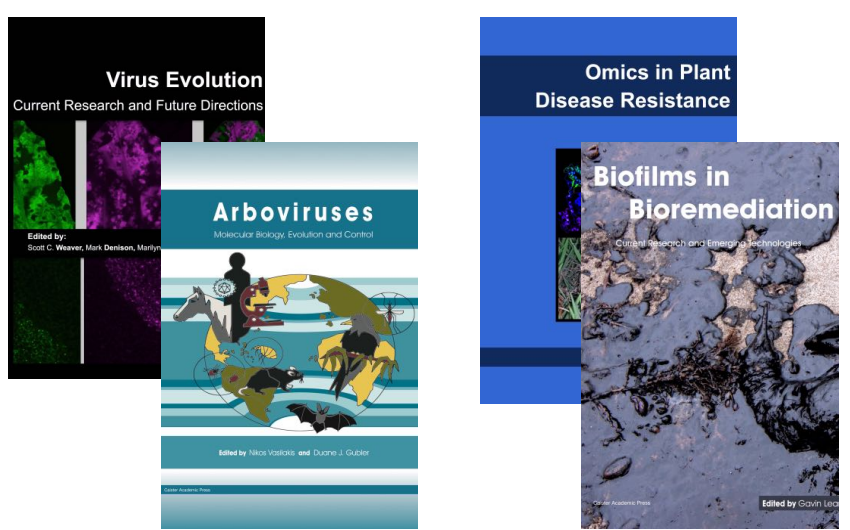
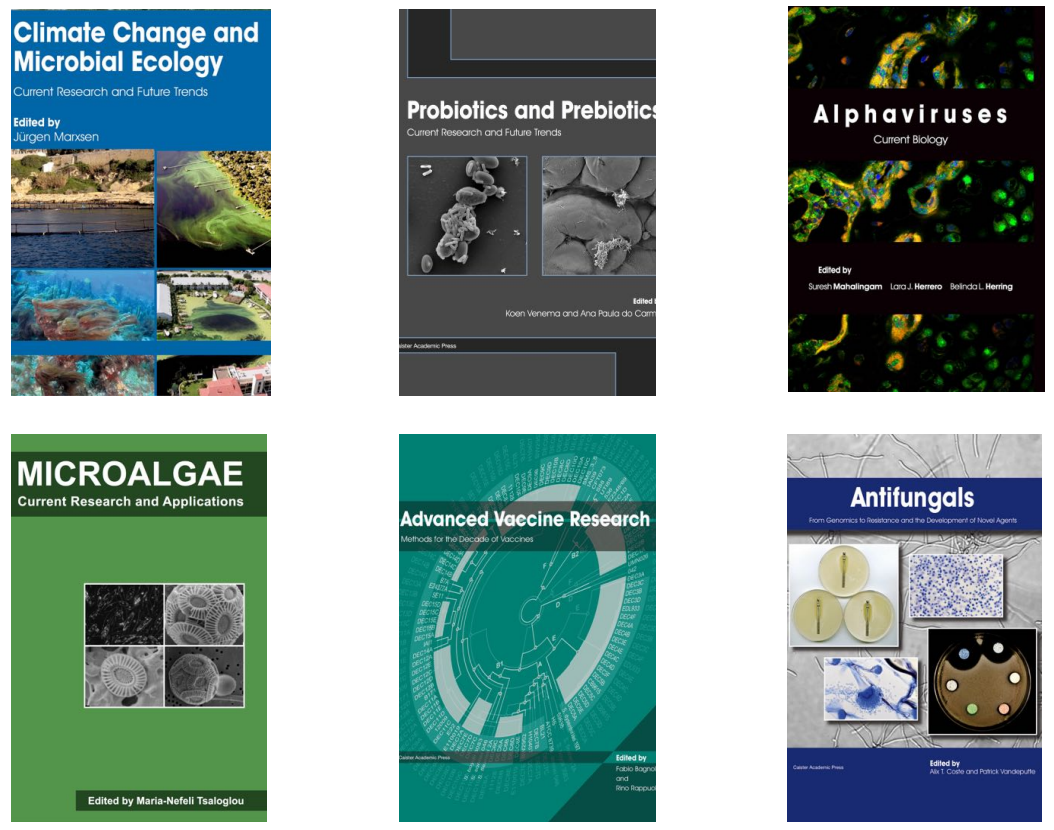

- Flow Cytometry in Microbiology: Technology and Applications Edited by: MG Wilkinson (2015) www.caister.com/flow

- Probiotics and Prebiotics: Current Research and Future Trends Edited by: K Venema, AP Carmo (2015) www.caister.com/probiotics

- Epigenetics: Current Research and Emerging Trends Edited by: BP Chadwick (2015) www.caister.com/epigenetics2015

- Corynebacterium glutamicum: From Systems Biology to Biotechnological Applications

Edited by: A Burkovski (2015)

www.caister.com/cory2

- Advanced Vaccine Research Methods for the Decade of Vaccines

Edited by: F Bagnoli, R Rappuoli (2015)

www.caister.com/vaccines

- Antifungals: From Genomics to Resistance and the Development of Novel Agents

Edited by: AT Coste, P Vandeputte (2015)

www.caister.com/antifungals

- Bacteria-Plant Interactions: Advanced Research and Future Trends Edited by: J Murillo, BA Vinatzer, RW Jackson, et al. (2015) www.caister.com/bacteria-plant

\section{- Aeromonas}

Edited by: J Graf (2015)

www.caister.com/aeromonas

- Antibiotics: Current Innovations and Future Trends

Edited by: S Sánchez, AL Demain (2015)

www.caister.com/antibiotics

- Leishmania: Current Biology and Contro Edited by: S Adak, R Datta (2015) www.caister.com/leish2

- Acanthamoeba: Biology and Pathogenesis (2nd edition) Author: NA Khan (2015)

www.caister.com/acanthamoeba2

- Microarrays: Current Technology, Innovations and Applications Edited by: Z He (2014)

www.caister.com/microarrays2

- Metagenomics of the Microbial Nitrogen Cycle: Theory, Methods and Applications

Edited by: D Marco (2014)

www.caister.com/n2 